\title{
Polymorphism identification in the goat THRSP gene and association analysis with growth traits
}

Xiaopeng An*, Haibo Zhao*, Long Bai', Jinxing Hou*, Jiayin Peng, Jiangang Wang, Yuxuan Song and Binyun Cao

College of Animal Science and Technology, Northwest A\&F University, Yangling, Shaanxi 712100, PR China

\begin{abstract}
In this study, we reported the analysis of THRSP gene polymorphisms in 610 goats of three breeds: Xinong Saanen (SN), Guanzhong (GZ) and Boer (BG). We identified new allelic variant: P2-G39294A (GenBank acc. no. JN618075) in the three goat breeds. At P2 locus, GG, GA and $A A$ genotypes were found in the three goat breeds. The frequencies of $G$ allele were 0.54 0.55 and frequencies of $A$ allele were $0.46-0.45$, and the PIC was 0.37 . The SNP locus was in Hardy-Weinberg disequilibrium in Boer goat breed $(P<0.05)$. Association of polymorphisms with growth traits was done at P2 locus in Boer goat breed. The result showed that AA genotype had remarkable growth traits at $P 2$ locus $(P<0.05)$. Therefore, these results suggest that THRSP gene is a strong candidate gene that affects growth traits in goat.
\end{abstract}

Keywords: variant, Boer goat, THRSP, growth traits

\section{Introduction}

The physiological regulation of growth traits is under the control of multiple genes, which may be important candidates for unraveling the genetic variation in economically relevant traits in farm animals (Wu et al. 2008, An et al. 2010). Availability of genetic information, particularly for those loci which affect performance traits may be important tools in breeding program. The use of molecular genetic technologies potentially offer a way to select a breeding animal for a wide range of traits at an early age (even embryos) and to enhance reliability in predicting the mature phenotype of the individual (Selvaggi et al. 2009).

Thyroid hormone responsive (THRSP) gene encodes a small acidic protein expressed predominately in the lactating mammary gland, fat, and liver (Zhan et al. 2006). THRSP mRNA levels are greatly increased by carbohydrate feeding or insulin-injection and decreased by high plasma glucagon levels or by feeding a diet rich in polyunsaturated fatty acids (Jump et al. 1993). Invernizzi et al. (2010) reported that expression of THRSP decreased by day 7 with both diets (saturated lipid and a blend of fish/soybean oil) and returned to basal levels by day 21 in bovine mammary tissue. THRSP is an important transcription factor that controls the expression of several lipogenic genes (Towle et al. 1997). In humans, THRSP gene was shown to be associated with obesity (Chagnon et al. 1998), growth, and differentiation of breast cancer cells (Sanchez-Rodriguez et al. 2005). The messenger RNA expression of THRSP was highly correlated

\footnotetext{
${ }^{*}$ These authors equally contributed to this paper.
} 
with intramuscular fat content of an individual in Wagyu $\times$ Hereford cattle (Wang et al. 2009). Research showed that the THRSP gene has impact on chicken fat metabolism (Breuker et al. 2010) and SNPs could be used in molecular marker assistant selection (MAS) as a genetic marker for the chicken and pig growth traits (Wang et al. 2004, d'Andre Hirwa et al. 2010, Chen et al. 2011). However, up to now, the research about SNPs of the THRSP gene was not reported in goat. The objectives of the present study were to identify SNPs of THRSP gene in three goat breeds and to evaluate associations between the polymorphisms and growth traits in Boer goats.

\section{Material and methods}

\section{Sample collection and DNA extraction}

Blood samples were obtained from 610 goats belonging to three breeds: Xinong Saanen (SN, $\mathrm{n}=196)$, Guanzhong ( $\mathrm{GZ}, \mathrm{n}=198)$ and Boer (BG, $\mathrm{n}=216)$. Xinong Saanen and Guanzhong are dairy breeds, while Boer is a very important breed for mutton production in China. They were reared, respectively, in Qianyang county of Shaanxi province $\left(34^{\circ} 39^{\prime} \mathrm{N}, 107^{\circ} 7^{\prime} 48^{\prime \prime} \mathrm{E}\right.$ and $830 \mathrm{~m}$ altitude), Zhouzhi county of Shaanxi province ( $34^{\circ} 14^{\prime} \mathrm{N}, 108^{\circ} 37^{\prime} \mathrm{E}$ and $1000 \mathrm{~m}$ altitude) and Linyou county of Shaanxi province $\left(34^{\circ} 42^{\prime} \mathrm{N}, 107^{\circ} 48^{\prime} \mathrm{E}\right.$ and $740 \mathrm{~m}$ altitude). The growth traits (3-months old) of 216 Boer goats from the same farm were recorded for statistical analysis. The following traits were evaluated: body weight, withers height, body length and chest girth. Five milliliters blood was collected aseptically from the jugular vein in a tube containing anticoagulant ACD (citric acid:sodium citrate:dextrose-10:27:38). All samples were delivered back to the laboratory in an ice box. The genomic DNA was extracted from white blood cells using standard phenol-chloroform extraction protocol.

\section{PCR conditions}

According to bovine THRSP gene (GenBank acc. no. NC_007330), five pairs of primers were designed to amplify goat THRSP gene and screened for polymorphisms. Only Primer 2 (P2 locus) has polymorphism. The $25 \mu \mathrm{L}$ reaction mixture contained $50 \mathrm{ng}$ genomic DNA, $0.5 \mu \mathrm{M}$ of each primer, $1 \times$ Buffer (including $1.5 \mathrm{~mm} \mathrm{MgCl}$ ), $200 \mu \mathrm{M}$ dNTPs and $0.625 \mathrm{U}$ Taq DNA polymerase (MBI). The cycling protocol was 5 min at $95^{\circ} \mathrm{C}, 35$ cycles of denaturing at $94^{\circ} \mathrm{C}$ for $30 \mathrm{~s}$, annealing at $57^{\circ} \mathrm{C}$ for $30 \mathrm{~s}$, extending at $72^{\circ} \mathrm{C}$ for $35 \mathrm{~s}$, with a final extension at $72^{\circ} \mathrm{C}$ for $10 \mathrm{~min}$.

Table 1

Primer sequences and information of THRSP gene

\begin{tabular}{|c|c|c|c|c|}
\hline Name & Sequence, bp & Temp., ${ }^{\circ} \mathrm{C}$ & Amplicon & Product size, bp \\
\hline \multirow[t]{2}{*}{ Primer 1} & F: 5- CAA GAA CTG CCT GCT GAC-3 & 51 & Exon 1 & 440 \\
\hline & R: 5-ACC ATT ACC TTT CCT ACA CG-3 & & & \\
\hline \multirow[t]{2}{*}{ Primer 2} & F: 5-CCA AAC TGC CAA CTT CAA CC-3 & 57 & Intron 1 (3162-3587) & 426 \\
\hline & R: 5-TCA CTG CTC TGC CAT CCC TA-3 & & & \\
\hline \multirow[t]{2}{*}{ Primer 3} & F: 5-GCA TCT GGT CCC ATC ACT TC-3 & 57 & Intron 1 (4045-4275) & 231 \\
\hline & R: 5-GGC ACT CAG CCT TCT TCA CA-3 & & & \\
\hline \multirow[t]{2}{*}{ Primer 4} & F: 5-TGC CAA CAA AGG TCC GTC TA-3 & 58 & Intron 1 (4232-4476) & 245 \\
\hline & R: 5-AAT CCC TCC CAG CAT CAG TC-3 & & & \\
\hline \multirow[t]{2}{*}{ Primer 5} & F: 5-TCA TCA CTG CGT CAC CGT TAG-3 & 56 & Exon 2 & 360 \\
\hline & R: 5-TCG GCT TCT TAG TTC TGT AGG-3 & & & \\
\hline
\end{tabular}




\section{SNP detection and DNA sequencing}

PCR products $(6 \mu \mathrm{L})$ were mixed with $8 \mu \mathrm{L}$ denaturing solution $(95 \%$ formamide, $25 \mathrm{~mm}$ EDTA, $0.025 \%$ xylene cyanole and $0.025 \%$ bromophenol blue), heated for $10 \mathrm{~min}$ at $98^{\circ} \mathrm{C}$ and chilled on ice. Denatured DNA samples were subjected to PAGE $(80 \times 73 \times 0.75 \mathrm{~mm})$ in $1 \times$ TBE buffer and constant voltage (190 V) for $3.5 \mathrm{~h}$. The gel (29:1 acrylamide:bis) was stained with $0.1 \%$ silver nitrate (He et al. 2011). After the polymorphisms had been detected, amplicons representing unique banding patterns were sequenced in both directions in $A B I 377$ DNA analyzer (Applied Biosystems, Foster City, CA, USA) and the sequences were analyzed with Lasergene 7.1 (DNAStar, Madison, WI, USA) and BLAST (National Center for Biotechnology Information, Bethesda, MD, USA).

\section{Statistical analysis}

The allelic frequency, heterozygosity (He), Hardy-Weinberg equilibrium and polymorphism information content (PIC) were calculated using Genepop software 4.0 (Rousset 2008). The software SPSS 16 (SPSS Inc., Chicago, IL, USA) was used to analyze the relationship between genotypes and growth traits in goats. Adjusted linear model:

$$
Y_{i j / m}=\mu+S_{i}+D_{i j}+G_{l}+E_{i j / m}
$$

where $Y_{i j / m}$ is the trait measured on each of the $i j / m$-th animal, $\mu$ is the overall population mean, $S_{i}$ is the fixed effect associated with the $i$-th sire, $D_{i j}$ is the fixed effect associated with $j$-th dam with sire $i$-th, $G$, is the fixed effect associated with $/$-th genotype, and $E_{i j / m}$ is the random error. Effects associated with farm and season of birth (spring vs fall) are not matched in the linear model, as the preliminary statistical analyses indicated that these effects did not have a significant influence on variability of traits in the analyzed breeds.

\section{Results and discussion}

According to international practice and reference to (Brka et al. 2010, Kulig et al. 2010, An et al. 2011) about the naming of SSCP patterns, In P2 locus, different SSCP patterns were named GG, $\mathrm{GA}$ and $\mathrm{AA}$ genotypes. The alleles were named $\mathrm{G}$ and $\mathrm{A}$, and $\mathrm{GG}, \mathrm{GA}$ and $\mathrm{AA}$ genotypes were found in the three goat breeds. The frequencies of $G$ allele were $0.54-0.55$ and frequencies of A allele were $0.46-0.45$, and the PIC was 0.37 (Table 2). According to the classification of PIC (low polymorphism if PIC value $<0.25$, moderate polymorphism if $0.25<\mathrm{PIC}$ value $<0.50$, and high polymorphism if PIC >0.50) (Ma et al. 2011), the three goat breeds at P2 locus had moderate genetic diversity. The P2 locus were in Hardy-Weinberg equilibrium in SN and GZ breeds $(P>0.05)$, which showed the genotypic frequencies has not been affected by selection, mutation or migration in both goat breeds. In BG breed, the P2 locus were in Hardy-Weinberg disequilibrium $(P<0.05)$, which suggested the genotypic frequencies were subjected to selection, mutation or migration in the breed. Only Boer goat was not in Hardy-Weinberg equilibrium at P2 locus which may be caused by specific selection for mutton production which affects the genotypes directly or indirectly. Hence, the goat THRSP gene was considered to have positive effects on growth traits. At P2 locus, the different electrophoresis patterns of $\mathrm{PCR}$ products were sequenced in both directions, and comparisons among these nucleotide 
sequences of difference genotypes indicated that one base substitution (P2-G39294A, GenBank acc. no. JN618075) were detected. In order to study the possible association between the carriers of different genotypes and the trait values, growth traits from 3-months old were analyzed in Boer goat breed (Table 3). At P2 locus, the does with AA genotype had greater body weight than those with $\mathrm{GG}$ and $\mathrm{GA}$ genotypes $(P<0.05)$; in addition, the does with $\mathrm{AA}$ genotype had greater chest girth than those with GA genotype $(P<0.05)$. We consider that these associations can be explained by the following two possible reasons: (1) Although this mutation of $\mathrm{P} 2$ locus does not concern the coding region, it possibly influences the stability of the mRNA, can affect the mechanism of mRNA deadenylation and degradation (Gallie \& Young 1994, Clement et al. 2001). (2) Linkage disequilibrium with the causal mutation possibly affects the variation of the growth traits in goat. If this polymorphism is in linkage disequilibrium with a gene affecting the variation of the growth traits, segregation based on marker alleles would result in phenotypic differences (Van der Werf et al. 2007). The mutations found might not be the causal mutation by themselves, but might be in linkage disequilibrium with the causal mutation which could affect either the THRSP gene or other genes near to the THRSP locus. Chen et al. (2011) implied the association of polymorphism at G123A and A308G sites in THRSP gene with lipogenesis capability of pigs and their important regulating role in the expression of lipogenesis genes in pigs. Expression analysis by real-time quantitative PCR showed that THRSP paralogs in ducks were more actively transcribed in fat tissues than in liver (Zhan et al. 2006). Wang et al. (2004) reported THRSPa locus was associated with abdominal fat traits in a broiler $\times$ Leghorn resource population. The $\mathrm{A} 213 \mathrm{C}$ and $9 \mathrm{bp}$ insertion-deletion of exon 1 in the THRSP gene was found to be associated with body weight in the chicken (Cao et al. 2007).

Table 2

Genotypic distribution, allelic frequencies of P2 locus in three goat breeds

\begin{tabular}{lcccc}
\hline & & & Breed & \\
& & SN & GZ & BG \\
\hline Genotype & GG & 59 & 62 & 56 \\
& GA & 97 & 90 & 125 \\
Allele & AA & 40 & 46 & 35 \\
& G & 0.55 & 0.54 & 0.55 \\
He & $\mathrm{A}$ & 0.45 & 0.46 & 0.45 \\
PIC & & 0.49 & 0.45 & 0.59 \\
Equilibrium & & 0.37 & 0.37 & 0.37 \\
$X^{2}$ test & $P>0.05$ & $P>0.05$ & $P<0.05$ \\
\hline
\end{tabular}

Table 3

Effects of THRSP genotypes on growth traits at P2 locus in Boer goats

\begin{tabular}{lcccc}
\hline Genotype & Body weight, $\mathrm{kg}$ & Withers height, $\mathrm{cm}$ & Body length, $\mathrm{cm}$ & Chest girth, $\mathrm{cm}$ \\
\hline GG & $15.00 \pm 0.30^{\mathrm{a}}$ & $44.98 \pm 0.43$ & $45.68 \pm 0.39$ & $54.63 \pm 0.52$ \\
GA & $14.95 \pm 0.20^{\mathrm{a}}$ & $45.06 \pm 0.29$ & $46.07 \pm 0.26$ & $54.49 \pm 0.35^{\mathrm{a}}$ \\
AA & $15.97 \pm 0.37^{\mathrm{b}}$ & $44.63 \pm 0.55$ & $45.89 \pm 0.50$ & $56.00 \pm 0.65^{\mathrm{b}}$ \\
\hline
\end{tabular}

The data are expressed as least square means \pm standard errors. Values with different superscripts within the same column differ significantly at $P<0.05$. 
This supports the notion that further investigation of THRSP variation in different goat breeds is needed. Till now, the association of THRSP genetic variations with growth traits has not been reported in domestic ruminant. The biochemical and physiological functions, together with the results obtained in our study, indicate that the THRSP gene might play important roles affecting growth traits in goat.

In conclusion the mutation (G39294A) we have identified in the intron 1 of THRSP gene could be potential genetic markers for growth traits in goats.

\section{Acknowledgement}

This study was supported by the National Science and Technology Program of China (2011BAD28B05-3) and the »13115« Sci-Tech Innovation Programme of Shaanxi Province (2009ZDKG-19).

\section{References}

An XP, Hou JX, Wang LX, Li G, Wang JG, Song YX, Zhou GQ, Han D, Ling L, Cao BY (2010) Novel polymorphisms of the growth hormone gene and their effect on growth traits in Chinese goats. Meat Sci 86, 758-763

An XP, Song SG, Hou JX, Zhu cm, Peng JX, Liu XQ, Liu HY, Xiao WP, Zhao HP, Bai L, Wang JG, Song YX, Cao BY (2011) Polymorphism identification in goat DGAT2 gene and association analysis with milk yield and fat percentage. Small Rumin Res 100, 107-112

Chagnon YC, Pérusse L, Bouchard C (1998) The human obesity gene map: The 1997 update. Obes Res 6, 76-92

Breuker C, Moreau A, Lakhal L, Tamasi V, Parmentier Y, Meyer U, Maurel P, Lumbroso S, Vilarem MJ, Pascussi JM (2010) Hepatic Expression of Thyroid Hormone-Responsive Spot 14 Protein Is Regulated by Constitutive Androstane Receptor (NR113). Endocrinology 151, 1653-1661

Brka M, Hodžić A, Reinsch N, Zečevic E, Dokso A, Djedović R, Rukavina D, Kapur L, Vegara M, Šabanović M, Ravić I (2010) Polymorphism of the kappa-casein gene in two Bosnian autochthonous cattle breeds. Arch Tierz 53, 277-282

Cao ZP, Wang SZ, Wang QG, Wang YX, Li H (2007) Association of spotl4 alpha gene polymorphisms with body weight in the chicken. Poult Sci 86, 1873-1880

Chen HQ, Zhou QQ, Wei HQ, Qin J, Chen H, Zhang YP (2011) [Association of Polymorphism in The Coding Region of THRSP Gene With Lipogenesis Capability in Pigs]. Prog Biochem Biophys 38, $84-90$ [in Chinese]

Clement JQ, Maiti S, Wilkinson MF (2001) Localization and stability of introns spliced from the Pem homeobox gene. J Biol Chem 276, 16919-16930

d'Andre Hirwa C, Yan W, Wallace P, Nie Q, Luo C, Li H, Shen X, Sun L, Tang J, Li W, Zhu X, Yang G, Zhang X (2010) Effects of the thyroid hormone responsive spot 14alpha gene on chicken growth and fat traits. Poult Sci 89, 1981-1991

Gallie DR, Young TE (1994) The regulation of gene expression in transformed maize aleurone and endosperm protoplasts-analysis of promoter activity, intron enhancement, and mRNA untranslated regions on expression. Plant Physiol 106, 929-939

He H, Liu XL, Gu YL, Liu Y (2011) Assessment of haplotype variation in bovine AMPD1 gene for association with growth and carcass traits in Qinchuan beef cattle. Arch Tierz 54, 18-26

Invernizzi G, Thering BJ, McGuire MA, Savoini G, Loor JJ (2010) Sustained upregulation of stearoyl-CoA desaturase in bovine mammary tissue with contrasting changes in milk fat synthesis and lipogenic gene networks caused by lipid supplements. Funct Integr Genomics 10, 561-575

Jump DB, Clarke SD, MacDougald O, Thelen A (1993) Polyunsaturated Fatty-Acids Inhibit S14 GeneTranscription in Rat Liver and Cultured Hepatocytes. Proc Natl Acad Sci USA 90, 8454-8458 
Kulig H, Kowalewska-Łuczak I, Kmieć M (2010) Effect of SCD SNPs on milk production traits of Jersey cows. Arch Tierz 53, 116-118

Ma L, Qu YJ, Huai YT, Li ZJ, Wang J, Lan XY, Zhang CL, Wang JQ, Chen H (2011) Polymorphisms identification and associations of KLF7 gene with cattle growth traits. Livest Sci 135, 1-7

Rousset F (2008) Genepop'007: a complete reimplementation of the Genepop software for Windows and Linux. Mol Ecol Resour 8, 103-106

Sanchez-Rodriguez J, Kaninda-Tshilumbu JP, Perez-Castillo A, Santos A (2005) The spot 14 protein inhibits growth and induces differentiation and cell death of human MCF-7 breast cancer cells. Biochem J 390, 57-65

Selvaggi M, Dario C, Normanno G, Celano GV, Dario M (2009) Genetic polymorphism of STAT5A protein: relationships with production traits and milk composition in Italian Brown cattle. J Dairy Res 76, 441-445

Towle HC, Kaytor EN, Shih HM (1997) Regulation of the expression of lipogenic enzyme genes by carbohydrate. Annu Rev Nutr 17, 405-433

Van der Werf JHJ, Marshall K, Lee S (2007) Methods and experimental designs for detection of QTL in sheep and goats. Small Rumin Res 70, 21-31

Wang YH, Bower NI, Reverter A, Tan SH, De Jager N, Wang R, McWilliam SM, Cafe LM, Greenwood PL, Lehnert SA (2009) Gene expression patterns during intramuscular fat development in cattle. J Anim Sci 87, 119-130

Wang XF, Carre W, Zhou HJ, Lamont SJ, Cogburn LA (2004) Duplicated Spot 14 genes in the chicken: characterization and identification of polymorphisms associated with abdominal fat traits. Gene 332, 79-88

Wu Y, Liu XL, Hou SS, Wang J (2008) Single nucleotide polymorphism discovery of peroxisome proliferatorsactivated receptors gamma gene and its association with carcass traits in duck. Arch Tierz 51, 276-282

Zhan K, Hou ZC, Li HF, Xu GY, Zhao R, Yang N (2006) Molecular cloning and expression of the duplicated thyroid hormone responsive Spot 14 (THRSP) genes in ducks. Poult Sci 85, 1746-1754

Received 28 August 2011, accepted 11 November 2011.

Corresponding author:

Bin Yun Cao

email: caobinyun@yahoo.com.cn

No. 22 Xinong Road, College of Animal Science and Technology, Northwest A\&F University, Yangling, Shaanxi 712100, P.R. China 